\title{
Global Jack-Up Rig Behaviour Next to a Footprint
}

\section{J. Jun', Y. H. Kim², M. S. Hossain ${ }^{3}$, M. J. Cassidy ${ }^{4}$, Y. Hu ${ }^{5}$ and S. G. Park}

$4 \quad{ }^{1} \mathrm{PhD}$ Student, Centre for Offshore Foundation Systems (COFS), Oceans Graduate School, The

5 University of Western Australia, 35 Stirling Highway, Crawley, WA 6009, Australia, Tel: +61 (0)8

$6 \quad 6488$ 7725, Email: minjung.jun @ research.uwa.edu.au

$7{ }^{2}$ Corresponding Author, Research Fellow (PhD), Centre for Offshore Foundation Systems (COFS),

8 Oceans Graduate School, The University of Western Australia, 35 Stirling Highway, Crawley, WA

9 6009, Australia, Tel: +61 (0)8 6488 4316, Email: youngho.kim@uwa.edu.au

$10{ }^{3}$ Associate Professor (BEng, MEng, PhD, MIEAust), Centre for Offshore Foundation Systems

11 (COFS), Oceans Graduate School, The University of Western Australia, 35 Stirling Highway,

12 Crawley, WA 6009, Australia, Tel: +61 (0)8 6488 7358, Email: muhammad.hossain@uwa.edu.au

$13{ }^{4}$ Professor (FTSE, FIEAust, GAICD, DPhil), Dean and Professor of Civil Engineering, Melbourne

14 School of Engineering, Doug McDonell Building, The University of Melbourne, Victoria 3010,

15 Australia, Tel: +61 38344 6619, Email: mark.cassidy@unimelb.edu.au

$16{ }^{5}$ Professor (PhD, MIEAust), School of Civil, Environmental and Mining Engineering, The

17 University of Western Australia, 35 Stirling Highway, Crawley, WA 6009, Australia, Tel: +61 (0)8

186488 8182, Email: yuxia.hu@uwa.edu.au

$19{ }^{6}$ Senior Research Engineer (MS), Daewoo Shipbuilding \& Marine Engineering Co. Ltd. (DSME), 96,

20 Baegot 2-ro, Siheung-si, Gyeonggi-do, Republic of Korea Tel: +82 (0)31 2129 3598, Email:

21 sgpark8@dsme.co.kr

22 - Number of Words: 5315 (text only)

23 - Number of Tables: 04

24 - Number of Figures: 20 


\section{Global Jack-Up Rig Behaviour Next to a Footprint}

\section{ABSTRACT}

This paper reports the effect of the global behaviour of three-legged jack-up rigs due to the reinstallation of spudcan footings next to seabed footprints. Two reinstallation scenarios are discussed: (i) two legs first installed on flat ground, and then the third leg installed near a footprint (representing what is known as leg-by-leg preloading); and (ii) the three legs installed simultaneously (representing simultaneous preloading). The spudcan-soil interaction was simulated using a coupled Eulerian-Lagrangian (CEL) approach. A simplified global jack-up model was developed by considering an equivalent beam model for the hull and legs. The results of the jack-up installations are compared against the responses of the more common modelling of a spudcan with a fixed head condition. A detailed parametric study assessing the consequences of spudcan-footprint interactions, such as the risk of the jack-up and spudcan sliding towards the footprint centre, overturning of the jack-up rig and of structural failure of the jack-up leg due to excessive stresses, is also discussed. The ability of a recently developed novel spudcan with a flat base and 4 holes, coupled with the global jack-up model, to mitigate the consequences of spudcan-footprint interactions is highlighted.

Keywords: jack-up, spudcan-footprint interaction, spudcan, global behaviour, numerical modelling 


\section{INTRODUCTION}

Most offshore drilling in shallow to moderate water is performed from self-elevating jackup rigs due to their proven flexibility, mobility and cost-effectiveness [1,2]. Modern jackups typically consist of a buoyant triangular platform supported by three independent truss legs, each attached to a large-diameter spudcan. Jack-ups often return to sites where previous operations have left footprints in the seabed. As shown in Fig. 1, if one of the jackup legs is located near a footprint slope, there is a tendency for the spudcan to slide towards the centre of the footprint, inducing excessive lateral displacements and bending moments or rotations in the rig. These detrimental foundation behaviours can result in an inability to install the jack-up in the required position, the occurrence of leg splay, and, at worst, structural damage to the whole jack-up system. Spudcan-footprint interaction has been identified as the second most common reason for the geotechnical failure of jack-ups [3].

To alleviate this issue, the first step was to investigate the performance of a spudcan installation next to a footprint. Due to both physical testing and numerical simulation challenges, the problem was simplified by considering a single cylindrical leg attached to a flat plate or generic spudcan and either a fixed head condition at the top of the leg [4-10] or a free head condition that allows sliding of the leg [11-13]. The soil failure mechanisms were exposed, the underlying behaviour was elucidated, and the critical offset ratio $\lambda$ (defined as $\lambda=\beta / D$, where $\beta$ is the distance between the footprint centre and the spudcan centre, and D is the spudcan diameter) was identified as $0.5 \sim 1$.

The following step was to explore potential mitigation measures. Thus far a number of measures have been trialled or examined, including: (a) infilling the crater $[14,15]$; (b) capping the infilled crater with gravel loading platforms; (c) stomping [15,16]; (d) reaming [16-18]; (e) perforation drilling [12]; (f) successive repositioning until the legs stabilise in the desired position [19]; (g) use of a spudcan with a diameter identical or very similar to the 
existing footprint diameter, placed in the same location as the existing footprint [20]; and (h) simultaneous water jetting and spudcan preloading [21]. In relation to the case histories in the North Sea, Jardine et al. and Grammatikopoulou et al. [15,22] examined the potential of using the former two measures. However, the results were mostly inconclusive or unsatisfactory. The pattern of soil movement became markedly asymmetrical, which led to intolerable forces and moments developing in the jack-up leg before the target preload level was reached. Infilling the crater with different type of soil created additional problems such as punch-through. Use of a gravel loading platform incurred the potential for slope-base failure. Stomping involves raising and lowering the jack-up leg over and away from the footprint to displace the soil towards the footprint. Jardine et al. [15] and Hartono [16] tested stomping and showed that it is effective in mitigating spudcan-footprint interactions where a spudcan penetrated up to the depth of initial penetration during creating the footprint. Reaming, also known as leg-working or leg reciprocation, was tested by Hartono [16] and Hartono et al. [17,18], varying strategies involving different amplitude of leg penetrationextraction cycles. It was found that reaming technique is only effective when a small amplitude of penetration-extraction cycle was used. Perforation drilling involves puncturing the soil by drilling a number of holes (and removing the soil) up to some depths beneath the footprint toe. Hossain \& Stainforth [12] showed that the removal of soil inside the spudcan perimeter, with an area of $9 \%$ perforated, is effective in easing spudcan-footprint interactions. However, all these techniques require additional mechanical operations to be carried out offshore, leading to additional cost and time.

Consequently, Hossain et al. and Jun et al.[13,23,24] have focused on adjusting spudcan shapes to ease spudcan-footprint interactions. These studies have led to the establishment of a novel spudcan shape with a flat base and 4 holes [24]; the flat base reduces the induced horizontal force on the bottom slope of the spudcan and the holes provide a preferential soil 
flow path and force the spudcan to penetrate vertically. It has been shown that this shape can effectively ease spudcan-footprint interaction issues such as reducing the induced horizontal force. However, like the previous research on traditional spudcans these studies have considered only a single leg or fixed head condition with a novel spudcan; hence, the results cannot reflect the global behaviour of a jack-up rig, which may undergo leg splay and rotation and is effected by the connecting hull and other two legs.

This study focuses on the effect of global jack-up rig behaviour on spudcan-footprint interactions. The investigation was carried out through 3D large-deformation finite element (LDFE) analyses of soil-structure interaction combining a global jack-up structure idealised by equivalent beam elements. Both leg-by-leg and simultaneous all-leg preloading processes [25], as commonly or sometimes used in the field, are considered with appropriate boundary conditions. An extensive parametric investigation was undertaken, varying the footprint geometry, soil strength and spudcan shape. Finally, the risk of sliding towards the footprint centre, overturning of the jack-up rig and structural failure were assessed by the proposed global jack-up modelling technique.

\section{NUMERICAL ANALYSIS}

3D LDFE analyses were carried out using the coupled Eulerian-Lagrangian (CEL) approach in the commercial Finite Element (FE) package ABAQUS/Explicit (Version 6.12) [26]. Qiu et al, Chen et al., Tho et al., Hu et al., Hamann et al., Kim and Hossain, Zheng et al. [27-35] have investigated various geotechnical problems using the CEL approach and provided evidence that it is applicable to solve problems involving large deformations. Extensive background information about CEL, spudcan installation and footprint modelling can be found in Jun et al., Zheng et al. and $\mathrm{Hu}$ et al. [23,24,35,36]; this information is not repeated here. 


\subsection{Modelling for spudcan-footprint interaction}

121 Considering the symmetry of the problem, half of the spudcan and soil were modelled. The

122 lateral extension of the soil domain was 4.0D from the centre of the spudcan ( $\mathrm{D}$ is the

123 spudcan diameter) on the spudcan penetration side and 3.0D on the opposite side, and the

124 depth of the soil domain was $\sim 5.5 \mathrm{D}$ to avoid boundary effects during the installation process

125 (as obtained from preliminary convergence studies and considered by researchers [23,35]).

126 Mesh convergence studies were performed to ensure that the mesh was sufficiently fine to

127 give accurate results. Five different mesh densities were considered in the fine mesh zone.

128 The numerical results based on two different minimum element sizes (e.g. $\mathrm{h}_{\min }=0.021 \mathrm{D}$ or

12911 elements per hole and $\mathrm{h}_{\min }=0.025 \mathrm{D}$ or 9 elements per hole) were almost identical,

130 indicating that mesh convergence was achieved with the density of $h_{\min }=0.025 \mathrm{D}[23,30]$.

131 Therefore, the typical soil element size along the trajectory of the spudcan (i.e., in the fine

132 mesh zone) was selected as $0.025 \mathrm{D}$. A footprint was made using a void. A typical mesh is

133 shown in Fig. 2.

134 A conical footprint (with diameter, $\mathrm{D}_{\mathrm{F}}=2 \mathrm{D}$ and depth, $\mathrm{z}_{\mathrm{F}}=0.33 \mathrm{D}$; see Fig. $2 \mathrm{~b}$ ) or a

135 cylindrical footprint (with diameter, $\mathrm{D}_{\mathrm{F}}=\mathrm{D}$ and depth, $\mathrm{z}_{\mathrm{F}}=0.66 \mathrm{D}$; see Fig. $2 \mathrm{c}$ ) with the soil

136 strength along and adjacent to the footprint identical to the intact strength profile was

137 considered. Generally, natural fine grained soils experience remoulding during a spudcan

138 penetration and extraction event. This disturbance is healed gradually with the passing of time

139 through dissipation of excess pore pressure [4,6]. The changes of strength in kaolin clay were

140 presented by Gan et al. [6] plotting strength contour as a function of the jack-up operational

141 period ( 0 and 2 years) and the intervening period before reinstallation ( 1 and 100 years).

142 Leung et al. [4] showed a full recovery of the original strength in kaolin takes 1 1.5 years in

143 the vicinity of the footprint. In this study, the soil strength along and adjacent to the footprint 
144 identical to the intact strength profile was considered because of two main reasons: (i)

145 removing the variety of possible strength gradients around the footprint has allowed for a

146 consistent evaluation of the benefits of a new global modelling technique (and comparisons

147 with the existing data from centrifuge tests [7] and numerical analyses [15], as reported by

148 Jun et al. [23,24]), (ii) due to the limitation of the current CEL approach and the used Tresca

149 soil model, it is not possible to capture the effect of the jack-up operational period and the

150 intervening period before reinstallation, and to maintain suction at the base of the extracting

151 spudcan $[37,38]$.

152 This study considered two different spudcan shapes: (a) a generic spudcan with a shape

153 similar to the spudcans of the 'Marathon LeTourneau Design, Class 82-SDC' jack-up rig

154 [39], and (b) a novel spudcan with a flat base and four holes [24] for easing spudcan-

155 footprint interaction issues. The details of these shapes are shown in Fig. 3. These spudcans

156 were simplified as a rigid body and connected to the jack-up rig (this will be discussed

157 later).

158 The penetration velocity of the spudcan (v) was assumed to be a constant of $0.1 \mathrm{~m} / \mathrm{s}$ referring

159 the parametric studies [30,40]. Note, with this constant penetration rate, the rapid leg run or

160 uncontrolled leg run cannot be considered. Typically, reinstallation of spudcans in clay is

161 completed under undrained conditions. Furthermore, in practice, natural soils exhibit strain-

162 rate dependency and also softens as they are sheared and remoulded. Thus, the soil was

163 modelled as an elasto-perfectly plastic material that obeys a Tresca yield criterion that was

164 extended to capture the combined effects of rate dependency and progressive softening

165 following Einav and Randolph [41]. The undrained shear strength at individual Gauss points

166 was modified immediately after each step, according to the average rate of shear strain in the

167 previous time step $(\dot{\gamma})$ and the current accumulated absolute plastic shear strain $(\xi)$, as 
$168 \mathrm{~s}_{\mathrm{u}}=\left[1+\mu \log \left(\frac{\operatorname{Max}\left(|\dot{\gamma}|, \dot{\gamma}_{\text {ref }}\right)}{\dot{\gamma}_{\text {ref }}}\right)\right]\left[\delta_{\text {rem }}+\left(1-\delta_{\text {rem }}\right) \mathrm{e}^{-3 \xi / \xi_{95}} \mathrm{~s}_{\mathrm{u}, \text { ref }}\right.$

169 The shear strain rate, $\dot{\gamma}$, within the soil was evaluated according to

$170 \quad \dot{\gamma}=\frac{\Delta \varepsilon_{1}-\Delta \varepsilon_{3}}{\Delta \mathrm{t}}$

171 where $\Delta \varepsilon_{1}$ and $\Delta \varepsilon_{3}$ are the cumulative major and minor principal strains, respectively, over

172 the incremental time. All the parameter definitions are given in the notation list. Further

173 details can be found in $[34,35,42]$. The importance of considering this extended soil model,

174 compared to a simple rate-independent and non-softened Tresca model, and corresponding

175 effects have recently been highlighted by spudcan-footprint interaction problems by Zhang 176 et al. [10], Hartono et al. [18], Jun et al. [23,24] and Zhang [43] for other problems by many

177 researchers e.g. Hossain and Randolph [42], Zhou and Randolph [44], Kim et al. [45] and

178 hence not repeated here. The soil-spudcan interface was modelled as frictional contact using a general contact algorithm with a limiting shear stress.

The mesh dependence of the strain softening behavior can be compensated by combining the

181 rate-dependent model (Needleman [46]; Sluys and De Borst [47]; Oka [48]; Zhou and

182 Randolph [44]). For that and for considering at least a reasonable operative shear strength,

183 combined rate dependency and progressive softening was implemented although the

184 considered constant penetration rate of $0.1 \mathrm{~m} / \mathrm{s}$ may not represent the rate during a spudcan

185 sliding towards a footprint centre. Further accuracy of this numerical model was confirmed

186 by Jun et al. [23,24] through e.g. mesh size exercise and validation exercise against 187 measured centrifuge test data. 


\subsection{Modelling for a simplified global jack-up rig}

190

191

192

193

194

195

196

197

198

199

200

201

202

To examine the global behaviour induced by spudcan-footprint interactions, a simplified jack-up rig was modelled, as shown in Fig. 2. According to the 'equivalent leg' and 'equivalent hull' model schemes [49], the legs and hull were constructed by 'beam' elements with equivalent properties; the properties of these elements are summarised in Table 1 . The hull and legs are generally connected by a jacking system (e.g., roller). In this study, this connection was modelled by 'beam connector' elements, allowing movement in vertical direction $\left(U_{z}=\right.$ free $)$ while maintaining the other degrees of freedom $\left(U_{x}, U_{y}, R_{x}, R_{y}\right.$ and $\left.R_{z}\right)$ fully coupled at the leg-hull connection [15]. The spudcan and a leg were connected by a 'MPC tie' (see Fig. 2), allowing the movement of all degrees of freedom $\left(U_{x}, U_{y}, U_{z}, R_{x}, R_{y}\right.$ and $\mathrm{R}_{\mathrm{z}}$ ) at the connection point. Symmetric conditions were applied to the overall model. In the field, a hull is generally submerged in shallow water (with a draft) during (at least) the initial preloading, particularly if a hazard (e.g., punch-through or spudcan-footprint interaction) was forecasted. The corresponding vertical buoyancy effect on the hull base was applied using a spring stiffness $\left(\mathrm{K}_{\text {buoy }}\right)$ according to

$$
\Delta \mathrm{s}=\frac{\Delta F_{\text {buoy }}}{K_{\text {buoy }}}
$$

where $\Delta \mathrm{s}$ is the hull vertical displacement, $\mathrm{K}_{\text {buoy }}\left(=\rho_{\text {sea }} \times \mathrm{g} \times \mathrm{A}_{\text {hull bottom }} /\right.$ number of springs $)$ is the spring stiffness of the static vertical buoyancy effect, and $\Delta \mathrm{F}_{\text {buoy }}$ is the changed static buoyancy force on the hull bottom (or the required force for $\Delta s$ ). $\rho_{\text {sea }}$ is the density of the sea water $\left(1.025 \mathrm{ton} / \mathrm{m}^{3}\right), \mathrm{g}$ is the acceleration of gravity $\left(9.81 \mathrm{~m} / \mathrm{s}^{2}\right)$, and $A_{\text {hull bottom }}$ is the hull base area. Although a controlled leg penetration $(0.1 \mathrm{~m} / \mathrm{s})$ was modelled, changes of bouncy were occurred due to the rotation of the hull, which was caused by the lateral displacement and rotation of the legs. Note that other environmental loads induced by winds, waves and 
212 currents were ignored, as it is usual for a relatively calm weather condition to be considered 213 during preloading [50].

\subsection{Modelling for penetration scenarios}

215 To reflect the preloading sequences in the field, two different preloading processes were 216 considered: (a) Preloading A, leg-by-leg preloading: two legs were first installed on the flat 217 ground, and then the third leg was penetrated (at a constant rate of $0.1 \mathrm{~m} / \mathrm{s}$ ) near a footprint 218 (see Fig. 4); (b) Preloading B, simultaneous preloading: all three legs were penetrated 219 simultaneously (at a constant rate of $0.1 \mathrm{~m} / \mathrm{s}$; see Fig. 5). To reduce the computational time, 220 the spudcans on the flat ground were replaced by foundation springs. The details of the 221 modelling techniques are described below.

222 Preloading A, leg-by-leg preloading: The spudcans installed on the flat ground were assumed to be pre-embedded to a depth of $0.25 \mathrm{D}$ [8]. The spudcans were replaced by attached foundation springs (see Fig. 4), and the stiffnesses were calculated according to the

$\mathrm{K}_{\mathrm{V}, \mathrm{ISO}}=\mathrm{K}_{\mathrm{dV}} \times 2 \mathrm{GD} /(1-\mathrm{U})$

(vertical stiffness)

$\mathrm{K}_{\mathrm{H}, \mathrm{ISO}}=\mathrm{K}_{\mathrm{dH}} \times 16 \mathrm{GD}(1-\mathrm{v}) /(7-8 \mathrm{v})$

(horizontal stiffness)

$\mathrm{K}_{\mathrm{M}, \mathrm{ISO}}=\mathrm{K}_{\mathrm{dM}} \times \mathrm{GD}^{3} / 3(1-\mathrm{v})$

(moment stiffness)

where $K_{d V}, K_{d H}$ and $K_{d M}$ are the stiffness depth factors, $G$ is the shear modulus of the

230 foundation soil and $v$ is Poisson's ratio of the soil. The third spudcan then penetrated the

231 footprint slope at a constant penetration velocity of $\mathrm{v}=0.1 \mathrm{~m} / \mathrm{s}$. Note that it was assumed

232 that a single leg penetration is carefully controlled by sequential filling and discharge of 233 preload ballast tanks around the leg to minimise the impact on the global moment 234 equilibrium [50]. 
Preloading B, simultaneous preloading: All legs are sometimes installed simultaneously, as reported by Amodio et al. [25] for a jack-up rig installation near an existing footprint. They employed simultaneous preloading of three legs in the initial preloading stage (see Fig. 5). The changes in the stiffness of the other two legs during this continuous penetration process cannot be represented by the foundation stiffness from the ISO guidelines [51], which give a constant stiffness at a given depth (Equations 3 5). Therefore, the evolution of stiffness was derived directly from a series of LDFE simulations considering the same soil and spudcan properties. For example, as shown in Fig. 6a, the simplified vertical stiffness $\left(\mathrm{K}_{\mathrm{V}, \mathrm{LDFE}}\right)$ was extracted from the results of penetration tests on the flat ground. In addition, the simplified horizontal $\left(\mathrm{K}_{\mathrm{H}, \mathrm{LDFE}}\right)$ and moment $\left(\mathrm{K}_{\mathrm{M}, \mathrm{LDFE}}\right)$ stiffness were obtained from lateral swipe and rotation tests at different depths $(\mathrm{d} / \mathrm{D}=0.0,0.1$ and 0.2$)$, respectively (see Fig. $6 \mathrm{~b}$ and $6 \mathrm{c})$. The correlation of the combined load components was not considered. This modelling approach is consistent with that followed by [52,53] for the study of monopoles and bucket foundations. The penetration velocity (v) of the three legs was assumed to be 0.1 $\mathrm{m} / \mathrm{s}$.

\section{RESULTS AND DISCUSSION}

To examine the effect of various factors on jack-up rig spudcan-footprint interactions, an extensive parametric study was carried out varying the (a) preloading processes (preloading A and preloading $\mathrm{B}),(\mathrm{b})$ soil strength $\left(\mathrm{s}_{\mathrm{u}, \mathrm{ref}}=2.4+1.35 \mathrm{z} \mathrm{kPa}\right.$ to represent soft clays and 50 $\mathrm{kPa}$ corresponding to very stiff clays), (c) footprint geometry $\left(\mathrm{D}_{\mathrm{F}}=2 \mathrm{D}\right.$ and $\mathrm{z}_{\mathrm{F}}=0.33 \mathrm{D}$ to represent footprints in soft clays, e.g., [20,54-56]; and $\mathrm{D}_{\mathrm{F}}=1 \mathrm{D}$ and $\mathrm{z}_{\mathrm{F}}=0.66 \mathrm{D}$ to represent footprints in moderate to stiff clays, e.g., [57]), and (d) spudcan shape (generic spudcan and novel spudcan; $\mathrm{D}=15 \mathrm{~m}$ ). The results from this parametric study, as assembled in Table 2, 
soil were assumed to be $\mu=0.1, \delta_{\text {rem }}=1 / \mathrm{S}_{\mathrm{t}}=1 / 3, \xi_{95}=15$, and $\dot{\gamma}_{\text {ref }}=1.5 \% \mathrm{~h}^{-1}$, as they

typically provided a good match with the data from the field and centrifuge tests $[23,35]$.

\subsection{Effect of preloading process and foundation stiffness}

262

The effect of the global behaviour of spudcan-footprint interactions was investigated by comparing the modelling results with those from single spudcan penetration analyses with a fixed head condition (infinite horizontal and rotational stiffness, allowing only vertical displacement). The soft clay conditions $\left(\mathrm{s}_{\mathrm{u}, \mathrm{ref}}=2.4+1.35 \mathrm{z}\right.$ in the Gulf of Mexico; [39]), conical footprint geometry $\left(D_{F}=2 D\right.$ and $z_{F}=0.33 D$; see Fig. $\left.2 b\right)$, and $\lambda=0.55$ were chosen from the field measurements and centrifuge tests. As noted previously, two different preloading processes were considered by using different types of foundation stiffness ( $\mathrm{K}_{\mathrm{ISO}}$ and $\mathrm{K}_{\mathrm{LDFE}}$ ). For simultaneous preloading (preloading $\mathrm{B}$ ), additional reduction of the foundation stiffness (e.g., $\omega \times \mathrm{K}_{\mathrm{LDFE}}$, where $\omega=0.1,0.3$ and 0.5 ) was considered to quantify the effect of the foundation stiffness. These reduced stiffness cases correspond to various spudcan embedment conditions and seabed soil strength heterogeneity, for instance, one leg penetrating the footprint slope while the other two legs are adjacent to a region that is lower than the footprint area. A similar approach using reduced stiffness was considered by Kong et al. [8].

Fig. 7 shows a comparison of the performance of the generic spudcan in terms of the horizontal $(\mathrm{H})$, vertical $(\mathrm{V})$, moment $(\mathrm{M})$ stiffnesses, lateral displacement $(\delta)$ and rotation distribution $(\theta)$ at the spudcan reference point RP (see Fig. 3) along the normalised penetration depth d/D. The corresponding soil failure mechanisms are displayed in Fig. 8. The profiles of the vertical force $(V)$ for the fixed head condition with the two global jackup rig preloading processes are very consistent (Fig. 7a). However, for preloading B, a reduced stiffness resulted in a reduced vertical resistance at shallow penetration depths $(d / D$ 
$<0.2$ ). This is due to sliding with the increasing lateral displacement allowing for a reduction in the resistance (see Fig. 7d). As shown in Fig. 8, during sliding, instead of vertical penetration, the movement of the spudcan along the footprint slope dominates the behaviour. The lateral sliding stops at approximately $\mathrm{d} / \mathrm{D}=0.2$ (the maximum lateral displacement, $\delta_{\max }=6.23 \mathrm{~m}$ for $\omega=0.1$ ), where the base of the spudcan is in full contact with the soil (see Fig. 8b); hence, the penetration resistance profile rises sharply and merges with those of the no sliding or minor sliding cases.

The induced horizontal force $(\mathrm{H})$ with global modelling is 8 $9 \%$ lower than that with the fixed head condition (0.93 0.94MN vs $1.02 \mathrm{MN}$; see Fig. 7b). This reduction arises mainly from the lateral sliding towards the footprint centre, diminishing the asymmetry of the soil failure mechanism (see Figs. 7d and 8). Relative to the fixed head condition, both reduction of $\mathrm{H}$ and lateral sliding displacement $\delta$ increase with decreasing stiffness K (Figs. 7b and 7d) confirms the previously identified explanation. The maximum horizontal force $\left(\mathrm{H}_{\max }\right)$ for $0.1 \times \mathrm{K}_{\mathrm{LDFE}}$ is $0.25 \mathrm{MN}$, which is approximately $75 \%$ lower than that for the fixed head condition $\left(\mathrm{H}_{\max }=1.02 \mathrm{MN}\right)$.

All the moments (M) in this parametric study are shown in Fig. 7c. The moment (M) at RP is mainly governed by the resultant vertical force (V) and its eccentricity from RP as the resultant horizontal forces nearly pass through RP [7,10,23-24]. As such, the differences in the maximum moment $\left(\mathbf{M}_{\max }\right)$ are not very large (see Fig. $\left.7 \mathrm{c}\right)$.

The lateral displacement, $\delta$, and rotation, $\theta$, are plotted in Fig. $7 \mathrm{~d}$ and $7 \mathrm{e}$, respectively. Both values are 0 regardless of the penetration depth for the fixed head condition, as the spudcan was forced to penetrate vertically. The maximum lateral displacements for preloading A and preloading $\mathrm{B}$ are respectively $\delta_{\max }=0.49 \mathrm{~m}$ and $0.55 \mathrm{~m}$, which increase with decreasing $\omega$ or stiffness (Fig. 7d). For instance, $\delta_{\max }=6.23 \mathrm{~m}$ for $\omega=0.1$. Interestingly, the trend is reversed for the rotation $\theta$. The maximum rotation value $\theta_{\max }$ is $-0.23^{\circ}$ for preloading $\mathrm{A}$ and 
$-0.13^{\circ}$ for preloading B. $\theta_{\max }$ decreases with $\omega$ or the stiffness (Fig. 7e). For instance, $\theta_{\max }=$ $-0.04^{\circ}$ for $\omega=0.1$. This is because of the domination of the global jack-up movement mechanism, translational to leg splay, as explained below.

Fig. 9 shows the schematic diagram for the relative lateral displacement $(\delta)$ and rotation $(\theta)$ at four characteristic locations in the jack-up rig: (a) location $\mathrm{A}\left(\Delta \delta_{\mathrm{a}}\right.$ and $\left.\Delta \theta_{\mathrm{a}}\right)$ is at the spudcan on the flat seabed; (b) locations B and $\mathrm{C}\left(\Delta \delta_{\mathrm{b}}, \Delta \delta_{\mathrm{c}}\right.$ and $\left.\Delta \theta_{\mathrm{b}}, \Delta \theta_{\mathrm{c}}\right)$ are at the connection between the hull and the leg; and (c) location $\mathrm{D}\left(\Delta \delta_{\mathrm{d}}\right.$ and $\left.\Delta \theta_{\mathrm{d}}\right)$ is at the spudcan near the footprint. The values of $\delta$ and $\theta$ for these four locations from the abovementioned analyses are summarised in Table 3 (note, Fig. $7 \mathrm{~d}$ and $7 \mathrm{e}$ show the resultant lateral displacement $\left(\delta=\Delta \delta_{\mathrm{a}}+\Delta \delta_{\mathrm{b}}+\Delta \delta_{\mathrm{c}}+\Delta \delta_{\mathrm{d}}\right)$ and rotation $\left(\theta=\Delta \theta_{\mathrm{a}}+\Delta \theta_{\mathrm{b}}+\Delta \theta_{\mathrm{c}}+\Delta \theta_{\mathrm{d}}\right)$, respectively, at location $\mathrm{D}$ ). For the relatively higher stiffness cases (i.e., $\mathrm{K}_{\mathrm{ISO}}$ and $\mathrm{K}_{\mathrm{LDFE}}$ ), the maximum lateral displacements occur at locations B and D, while the displacements at location $\mathrm{A}$ and $\mathrm{C}$ are minimal. This is because, for instance, at location $\mathrm{A}$, the actual lateral responses lie in the elastic zone of stiffness $K_{I S O}$ and $K_{\text {LDFE }}$ (see Fig. 10). This minimum lateral displacement at locations $\mathrm{A}$ and $\mathrm{C}$ and maximum lateral displacement at $\mathrm{B}$ and $\mathrm{D}$ results in leg splay of the global jack-up. However, by reducing the foundation stiffness $\left(\omega \times \mathrm{K}_{\mathrm{LDFE}}, \omega=0.1,0.3\right.$ and 0.5$)$, the displacements at location A increase remarkably (see Fig. 10), while those at B and D decrease. Therefore, the global jack-up deformation pattern changes to a horizontal translational mode (see insets in Fig. 10).

In all the cases, the rotation increments at location $\mathrm{D}\left(\Delta \theta_{\mathrm{d}}\right)$ are almost identical to the resultant rotation at the spudcan location $\mathrm{RP}(\theta$; see Table 3$)$. This attributes to the fact that the buoyancy spring stiffness $\left(\mathrm{K}_{\text {buoy }}\right)$ restricts the rotation of the hull, leading to the other rotation components compensating with each other $\left(\Delta \theta_{\mathrm{a}}+\Delta \theta_{\mathrm{b}}+\Delta \theta_{\mathrm{c}} \approx 0\right)$. 


\subsection{Evaluate structural integrity}

332 With the global jack-up modelling technique, the structural integrity of the jack-up leg can

333 be assessed. To generate a large horizontal force (and hence the leg failure load) from the

334 spudcan-footprint interaction, a very stiff clay $\left(\mathrm{s}_{\mathrm{u}, \mathrm{ref}}=50 \mathrm{kPa}\right)$ and corresponding foundation

335 stiffness (e.g., $\mathrm{K}_{\mathrm{ISO}}$ ) were considered as pre-embedded conditions for the spudcan on the flat 336 ground. According to the centrifuge tests reported by Gan [54], a cylindrical footprint 337 geometry $\left(\mathrm{D}_{\mathrm{F}}=1.00 \mathrm{D}\right.$ and $\mathrm{z}_{\mathrm{F}}=0.66 \mathrm{D}$; typical footprint geometry in stiff clay; see Fig. 2c) 338 and $\lambda=0.5$ were selected.

339 The spudcan responses and corresponding failure mechanisms from the global jack-up 340 modelling are presented in Fig. 11 and 12, respectively. The results from a single spudcan 341 penetration with a fixed head condition are also included in Fig. 11 for comparison.

342 Consistent with Fig. 7, the global responses (vertical load, horizontal load and moment in 343 Fig. 11) are lower than the fixed head responses. However, as expected, the lateral 344 displacement and rotation are greater for the global jack-up.

345 By comparing with the results in Fig. 7, all the spudcan responses for a deep cylindrical 346 footprint in stiff clay are significantly higher than the corresponding results for a shallow 347 conical footprint in soft clay, although the offsets of the spudcan penetration are very similar, $348 \lambda=0.5$ (Fig. 11) and 0.55 (Fig. 7). For instance, the maximum horizontal force $\left(\mathrm{H}_{\max }\right)$ is $682 \%$

349 greater for a deep cylindrical footprint. This is because of the more profound asymmetric 350 soil flow to deeper penetration depths, as can be observed by comparing the soil failure 351 mechanisms between Fig. 8 and 12, and the increased undrained shear strength. In addition, 352 the global modelling confirms that the lateral sliding towards the footprint centre reduces the 353 induced horizontal force.

354 Fig. 7c and 11c plot the moment at RP at the spudcan centre, nominally nulling the 355 influence of the resultant horizontal force $\mathrm{H}$, as it nearly passes through the RP. However, if 
the reference point is shifted to the point connecting the leg with the hull, the resultant horizontal force $\mathrm{H}$ will add additional moment $\left(=\mathrm{H} \times \mathrm{L}_{\mathrm{leg}}\right)$ and dominate the moment response $[23,24]$. If the consequent stress on the leg exceeds its structural capacity, the leg can be damaged. For example, Fig. 13a plots the moment at the leg top for the preloading A

360 ( $\left.\mathrm{K}_{\mathrm{ISO}}\right)$ case shown in Fig. 11c. Clearly, the moment direction is reversed, and the magnitude of the maximum moment is significantly higher (-467.5 MN vs $72 \mathrm{MN})$. Fig. 13b shows that the beam stress distribution on the leg interacts with the footprint just below the hull $(150 \mathrm{~m}$ above the soil surface), which is captured directly from the global jack-up modelling. The beam stress can be divided into two components: (a) pure axial stress from the vertical force (e.g., penetration resistance) and (b) bending stress from the spudcan-footprint interaction 366 (i.e., horizontal force, moment, leg eccentricity; see inset in Fig. 13b). In this case, the structural stability of the leg is dictated by the bending stress due to the effect of the spudcan-footprint interaction. For instance, when the maximum beam stress $\left(\sigma_{\text {beam,max }}\right)$ is approximately $-420.8 \mathrm{MPa}$, the axial stress $\left(\sigma_{\text {axial }}\right)$ is $-82.2 \mathrm{MPa}\left(19.5 \%\right.$ of $\left.\sigma_{\text {beam }}\right)$ and the

370 bending stress $\left(\sigma_{\text {bending }}\right)$ is $-338.6 \mathrm{MPa}\left(80.5 \%\right.$ of $\left.\sigma_{\text {beam }}\right)$. Fig. 13c shows the evolution of 371 structural stresses with the spudcan penetration depth $d / D$, allowing the identification of the 372 critical depth for attaining the maximum beam stress as $\mathrm{d} / \mathrm{D}_{\text {critical }}=0.45$.

373 In the analyses above, the jack-up legs were simplified according to the 'equivalent leg' 374 model scheme of SNAME [49]. To assess the structural integrity more precisely, an analysis 375 was performed by considering a truss leg, following the ISO design guideline [51]. From the 376 analyses above(e.g., Fig. 13), it was found that the maximum stress was concentrated on the 377 leg with the spudcan to be installed near the footprint, just beneath the connection of the hull 378 with the leg. As such, for this analysis, only a 37.5-m-long section of that leg from the hull379 leg connection point was considered, as shown in Fig. 14. For the boundary conditions, 380 three degrees of freedom (lateral displacement in the $\mathrm{x}$ direction, $\mathrm{U}_{\mathrm{x}}$, vertical displacement, 
$\mathrm{U}_{\mathrm{z}}$, and rotation in the $\mathrm{y}$ direction, $\mathrm{R}_{\mathrm{y}}$ ) at the top and bottom of the truss leg section were considered, while lateral displacement in the y direction (or perpendicular to the page), $\mathrm{U}_{\mathrm{y}}$, rotation in the $\mathrm{x}$ direction, $\mathrm{R}_{\mathrm{x}}$, and rotation in the vertical direction, $\mathrm{R}_{\mathrm{z}}$, were assumed to be zero due to the symmetric condition of the problem.

In ISO guidance [51], the structural stability requirement for the chord is suggested to be

$\left|\sigma_{\text {beam,max }}\right|<\sigma_{\text {criteria }}$

where $\sigma_{\text {criteria }}=\sigma_{\text {column buckling }} / \mathrm{F}_{\text {safety }}$

$\sigma_{\text {column buckling }}=\left(1.0-0.278 \times \chi^{2}\right) \times \sigma_{\text {yield }}$ for $\lambda \leq 1.34$

$$
=0.9 \times \sigma_{\text {yield }} / \chi^{2}
$$$$
\text { for } \lambda>1.34
$$

$\mathrm{F}_{\text {safety }}=$ resistance factor $=1.15$

$\chi=\left(\sigma_{\text {yield }} / \sigma_{\mathrm{E}}\right)^{0.5}$

$\sigma_{\mathrm{E}}=$ Euler buckling strength $=\pi^{2} \mathrm{E}_{\text {steel }} /\left(\mathrm{K} \times \mathrm{L}_{\text {bay }} / \mathrm{r}_{\mathrm{r} \& \mathrm{c}}\right)^{2}$

$$
\mathrm{K}=\text { column effective length factor }=1.0
$$

The yield strength $\left(\sigma_{\text {yield }}\right)$ for the chord typically ranges from 414 to $700 \mathrm{MPa}$ depending on the jack-up rig size and type [51]. $\mathrm{L}_{\text {bay }}$ is one bay length, $\mathrm{r}_{\mathrm{r} \& \mathrm{c}}$ is the radius of gyration of the rack and chord, and $\mathrm{E}_{\text {steel }}$ is Young's modulus of the steel. The considered dimensions and properties of the chord and brace are summarised in Table 4. According to Equation 6, $\sigma_{\text {criteria }}$ varies between 302.8 and $445.3 \mathrm{MPa}$.

Fig. 15 shows the results in terms of beam stresses in the leg. The maximum stress $(-398.8$ $\mathrm{MPa}$ ) occurs at the second (from the top) joint between the left chord and braces (see the zoomed-in figure of the left chord in Fig. 15). The maximum absolute value of the beam stress at the joint, $\left|\sigma_{\text {beam,max }}\right|=398.8 \mathrm{MPa}$, exceeds the lower bound of the design criteria, 302.8 $\mathrm{MPa}<\sigma_{\text {criteria }}<445.3 \mathrm{MPa}$ (calculated with Equation 6 and the input from Table 4). 
404 Therefore, $\left|\sigma_{\text {beam,max }}\right|>\sigma_{\text {criteria }}$, indicating that leg failure may occur if a leg of the jack-up rig

405 is installed on a deep cylindrical footprint in very stiff clay.

406 Interestingly, the maximum absolute beam stress from the global modelling with simplified 407 legs (-420.8 MPa in Fig. 13) closely predicts (just 5.5\% higher) the maximum stress from 408 the detailed truss leg analysis (398.8 MPa in Fig. 15). Although simplified leg modelling 409 cannot indicate the exact location of the likelihood of failure on the global jack-up structure, 410 a critical zone can be identified. Note that if the maximum absolute stress from the global 411 modelling with simplified legs $\left(\sigma_{\text {beam }}\right)$ is close to or exceeds the stability criterion $\left(\sigma_{\text {criteria }}\right)$, a 412 detailed truss leg analysis has to be conducted.

\section{$413 \quad 3.3$ Effect of novel spudcan}

414 From the previous investigations [13,23,24], it has been consistently found that spudcan 415 shape has a significant influence on spudcan-footprint interactions, leading to the 416 establishment of a novel spudcan shape, with a flat base and 4 holes, to ease spudcan417 footprint interaction issues. For example, the reduction of the maximum induced horizontal 418 force $\left(\mathrm{H}_{\max }\right)$ by the novel spudcan was approximately 30\% 42\% [24] and the reduction of 419 the lateral sliding distance was 74 98\% [13], in comparison to the results using a generic 420 spudcan. However, all the previous simulations or tests have been conducted considering a 421 single rigid leg with either a fixed head or free head (allowing lateral displacement of the 422 spudcan and leg together [13]) condition. In this study, the performance of the novel spudcan will be assessed through global jack-up rig modelling.

\section{$424 \quad$ Lateral sliding}

425 To check the effect of the novel spudcan on lateral sliding, a normal (preloading $\mathrm{B} ; \mathrm{K}_{\mathrm{LDFE}}$ ) 426 and a reduced (preloading $\mathrm{B} ; 0.1 \times \mathrm{K}_{\mathrm{LDFE}}$ ) foundation stiffness and a conical shallow 427 footprint geometry $\left(\mathrm{D}_{\mathrm{F}}=2 \mathrm{D}\right.$ and $\left.\mathrm{z}_{\mathrm{F}}=0.33 \mathrm{D}\right)$, were chosen. Fig. 16 shows the response 
profiles for both novel and generic spudcans as comparison. For the normal stiffness case, the novel spudcan reduces $H_{\max }$ by $31 \%$ and $\theta_{\max }$ by $23 \%$, but the values of $\mathrm{M}_{\max }$ (near RP) and $\delta_{\max }$ are very similar. In contrast, for the reduced stiffness case, the values of $H_{\max }, M_{\max }$ and $\theta_{\max }$ are similar, but the novel spudcan reduces $\delta_{\max }$ by $40 \%$. These results can be explained by the corresponding soil failure mechanisms depicted in Fig. 17. By comparing the mechanisms for the generic spudcan in Fig. 8, the flat-based underside profile and holes on the novel spudcan provide preferential soil flow paths, somewhat anchoring the spudcan on the right slide with earlier soil flow through the holes and forcing the spudcan to penetrate more vertically, reducing $\mathrm{H}_{\max }$ (for the normal stiffness case) or $\theta_{\max }$ (for the reduced stiffness case).

438 Note that the vertical resistance of the novel spudcan is lower than that of the generic 439 spudcan up to $\mathrm{d} / \mathrm{D}=\sim 0.25$ due to the reduced net area $\left(\mathrm{A}_{\text {net }}=141.4 \mathrm{~m}^{2}\right.$ for the novel 440 spudcan vs $176.7 \mathrm{~m}^{2}$ for the generic spudcan). Therefore, to confirm the mitigation 441 efficiency of the novel spudcan shape, an additional analysis was carried out on a large 442 novel spudcan of $\mathrm{D}=16.4 \mathrm{~m}$ (with $\mathrm{A}_{\text {net }}$ equal to the generic spudcan). Here, only the flat 443 base part was increased to get an identical $A_{\text {net }}$ (see inset in Figure 16). As expected, (i) the 444 vertical force for the large novel spudcan $(\mathrm{D}=16.4 \mathrm{~m})$ becomes similar to the generic 445 spudcan (Figure 16a), (ii) the horizontal force remains similar to the original novel spudcan 446 (Figure 16b) as the enlarged flat base did not mobilise additional horizontal force, and (iii) 447 the moment response increases significantly due to the enhanced imbalance vertical force 448 (Figure 16c). The effect of the holes has been reported extensively by Jun et al. [23, 24].

449 Leg failure

450 To examine the effect of the novel spudcan on the structural integrity, stiff clay with a 451 deeper footprint case, discussed in Fig. 11 15, was considered. The same analyses were 
452

carried out by replacing the generic spudcan with the novel spudcan. The results are shown in Fig. 18 20.

Compared to the response of the generic spudcan, the maximum horizontal force $\left(\mathrm{H}_{\max }\right)$, maximum moment $\left(\mathrm{M}_{\max }\right)$, maximum lateral displacement $\left(\delta_{\max }\right)$, and maximum rotation $\left(\theta_{\max }\right)$ are reduced by $34.2 \%, 19.2 \%, 31.5 \%$ and $22.6 \%$, respectively, by using the novel spudcan (see Fig. 18). With the progress of penetration, the soil flow beneath the generic spudcan is mainly directed towards the other side of the footprint wall (see Fig. 12a and b), whereas the soil at the base of the novel spudcan flows partly through the holes and partly towards the other side of the footprint wall (see Fig. 19a and b). The soil flow through the holes somewhat anchors the spudcan, limiting the lateral sliding of the spudcan towards the footprint centre.

Fig. 20a shows the stress distributions, as a function of the normalised spudcan penetration depth $d / D$, from the global modelling considering simplified beam legs. The critical spudcan penetration depth for attaining the maximum stress, $\mathrm{d} / \mathrm{D}_{\text {critical }}=0.5$, is similar to that $(0.45)$ for the generic spudcan (see Fig. 13c). However, the maximum beam stress of $\sigma_{\text {beam,max }}=-$ 315.9 $\mathrm{MPa}$ is $25 \%$ lower than that $(420.8 \mathrm{MPa})$ for the generic spudcan. Nevertheless, $\left|\sigma_{\text {beam,max }}\right|=315.9 \mathrm{MPa}$ exceeds the lower bound of the design criteria, 302.8 $\mathrm{MPa}<\sigma_{\text {criteria }}<$ 445.3 MPa. As such, a detailed truss leg analysis was carried out, and the stress distribution is shown in Fig. 20b. Again, the location of the maximum beam stress at the $2^{\text {nd }}$ (from the top) joint between the left chord and braces is consistent with the location of the maximum beam stress for the generic spudcan (see Fig. 15). However, the maximum beam stress of $\left|\sigma_{\text {beam,max }}\right|=298.6 \mathrm{MPa}$ is now less than the lower bound of the design criteria, $302.8 \mathrm{MPa}<$ $\sigma_{\text {criteria }}<445.3 \mathrm{MPa}$, meaning that the leg or jack-up rig will not fail if the novel spudcan is used. This confirms that tweaking the spudcan shapes (i.e., the underside profile and holes) 
has potential to ease spudcan-footprint interactions and increases the structural integrity of the jack-up rig.

\section{CONCLUDING REMARKS}

A global assessment of spudcan-footprint interactions was performed through modelling of a complete jack-up rig considering three simplified tubular legs connected by a hull than that performed using a single leg or fixed head condition. The influence of buoyancy on the hull draft was taken into account. The two routine preloading methods, i.e. leg-by-leg preloading and simultaneous preloading, were simulated. The jack-up rig was set up with one leg with its spudcan foundation near a footprint and the other two legs with their spudcans away from the footprint. The two spudcans away from the footprint were replaced by vertical horizontal and moment springs to simplify the analysis. The stiffness of the springs were obtained from the LDFE analyses and artificially reduced (to capture softer soil or surface footing case) the values. In addition, two soil strengths and two footprint geometries were explored. Advanced structural integrity analyses were carried out by considering global modelling with a tubular leg or truss leg to identify the potential and location of leg failure due to spudcan-footprint interactions. Finally, the performance of a recently proposed novel spudcan in the global jack-up rig was assessed. The following conclusions can be drawn.

Global jack-up rig modelling showed that induced horizontal force $\mathrm{H}_{\max }$ may be 8 9\% (for soft clay with a 2D wide and $0.33 \mathrm{D}$ deep footprint) and $15.9 \%$ (for stiff clay with a $1 \mathrm{D}$ wide and $0.66 \mathrm{D}$ deep footprint) lower compared to the fixed head condition. However, this study also provided an indication of the magnitude of the lateral spudcan displacement, with maximum displacements of $\delta_{\max }=0.45 \sim 0.55 \mathrm{~m}$ (for soft clay) to $3.43 \mathrm{~m}$ (for stiff clay), and maximum rotations of $\theta_{\max }=-0.13 \sim-0.23^{\circ}$ (for soft clay) and $-1.37^{\circ}$ (for stiff clay). The 
reduction of $\mathrm{H}$ with global modelling increased with decreasing stiffness $\mathrm{K}$ and increasing lateral sliding displacement $\delta$. The effect of preloading process was found to be insignificant. All the responses for a deep cylindrical footprint in stiff clay were significantly higher compared to the results for a shallow conical footprint in soft clay, with identical spudcan installation offset.

For the stiff clay with a $0.66 \mathrm{D}$ deep footprint and generic spudcan, the maximum beam stress occurred at a spudcan penetration depth of $0.5 \mathrm{D}$. Both the global analysis with a tubular leg and detailed truss leg analysis showed that the leg on the footprint would fail at the second (from the top) joint between the left chord and braces due to the beam stresses caused by spudcan-footprint interactions.

The novel spudcan with a flat base and 4 holes reduced $\mathrm{H}_{\max }$ by $31 \%$ and $\theta_{\max }$ by $23 \%$ (for soft clay with a $2 \mathrm{D}$ wide and $0.33 \mathrm{D}$ deep footprint) and $\mathrm{H}_{\max }$ by $34.2 \%, \delta_{\max }$ by $19.2 \%$ and $\theta_{\max }$ by $31.5 \%$ (for stiff clay with a $1 \mathrm{D}$ wide and $0.66 \mathrm{D}$ deep footprint) against the generic spudcan. More importantly for the cases studied here, from the detail truss leg analysis, the leg near the footprint, which would fail with the generic spudcan, may not fail with the novel spudcan.

Based on the results, the recommendations for the design of a spudcan penetration near a footprint can be proposed as

1. The responses are affected by the footprint geometry, offset distances, and spudcan shape.

2. To prevent the large lateral displacement towards the footprint centre, the horizontal resistance capacity at the other spudcans should be larger than the horizontal force induced by spudcan-footprint interactions.

3. The structural integrity of the leg must be checked against the predicted induced horizontal force and moment. 
4. The novel spudcan can be used for easing spudcan-footprint interactions.

526 All the analyses were performed considering a footprint with the soil strength along and adjacent to the footprint identical to the intact strength profile. The changes of soil strength during the formation of the footprint and subsequent jack-up operational period and the

529 intervening period before reinstallation was therefore not taken into account. Further

530 analyses are being carried out considering soil strength heterogeneity around the footprint.

531 Due to the limitation of the used LDFE technique and soil constitutive model, footprint was 532 not created in the real field way of penetration and extraction of a spudcan. Instead, the 533 footprint geometries and strength contour presented by Gan et al. [6] as a function of the 534 jack-up operational period and the intervening period before reinstallation were directly 535 mapped in the LDFE simulations. The results will be published in the future.

\section{ACKNOWLEDGEMENTS}

537 The research presented herein was undertaken with support from the Australian Research 538 Council (ARC) through Linkage Project LP140100066. The work forms part of the activities 539 of the Centre for Offshore Foundation Systems (COFS), currently supported as a node of the 540 Australian Research Council Centre of Excellence for Geotechnical Science and Engineering 541 and as a Centre of Excellence by the Lloyd's Register Foundation. This support is gratefully 542 acknowledged, as is the helpful discussion with Dr. Dong Wang. 


\section{REFERENCES}

[1] CLAROM. Design guides for offshore structures. Club des Actions de Recherche sur les Ouvrages en Mer, Eds: Le Tirant, P. \& Pérol, C., Paris; 1993.

[2] Randolph MF, Cassidy MJ, Gourvenec S, Erbrich CJ. (2005). Challenges of offshore geotechnical engineering. State of the art paper, Proc Int Conf on Soil Mech and Found Eng; 2005 Sep 12-15; Osaka, Japan. 2005. 1:123-76.

[3] MSL Engineering Limited for the Health and Safety Executive. Guidelines for jack-up rigs with particular reference to foundation integrity; 2004. Research Report 289.

[4] Leung CF, Gan CT, Chow YK. Shear strength changes within jack-up spudcan footprints. Proc $17^{\text {th }}$ Int Offshore and Polar Eng (ISOPE); 2007 Jul 1-6; Lisbon, Portugal. 2007. 2:1504-09.

[5] Cassidy MJ, Quah CK, Foo KS. Experimental investigation of the reinstallation of spudcan footings close to exiting footprints. J Geotech Geoenviron Eng (ASCE) $2009 ; 135(4): 474-86$.

[6] Gan CT, Leung CF, Cassidy MJ, Gaudin C, Chow YK. Effect of time on spudcanfootprint interaction in clay. Géotechnique 2012;62(5):401-13.

[7] Kong VW, Cassidy MJ, Gaudin C. Experimental study of the effect of geometry on reinstallation of jack-up next to footprint. Canadian Geotech J 2013;50(5):557-73.

[8] Kong VW, Cassidy MJ, Gaudin C. Development of a real-time hybrid testing method in a centrifuge. Int J Phys Modelling in Geotech 2015;15(4):169-90.

[9] Tho KK, Leung CF, Chow YK, Swaddiwudhipong S. Eulerian finite-element simulation of spudcan-pile interaction. Canadian Geotech J 2013;50(6):595-608.

[10] Zhang W, Cassidy MJ, Tian Y. 3D large deformation finite element analyses o jack-up reinstallations near idealised footprints. Proc 15th Int Conf on the Jack-up Platf: Design, Construction and Operation; 2015 Sep15-16; City University London, UK. 2015. 
[11] Gaudin C, Cassidy MJ, Donovan T. Spudcan reinstallation near existing footprints. Proc Offshore Site Investigation and Geotech Conf, Confronting New Challenges and Sharing Knowledge; 2007 Sep 11-13; London, UK. 2007. p. 285-92.

[12] Hossain MS, Stainforth R. Perforation drilling for easing spudcan-footprint interaction issues. Ocean Eng 2016;113:308-18.

[13] Hossain MS, Stainforth R, Ngo VT, Cassidy MJ, Kim YH, Jun MJ. Experimental investigation on the effect of spudcan shape on spudcan-footprint interaction. Appl Ocean Res 2017;69:65-75.

[14] Jardine RJ, Kovecevic N, Hoyle MJR, Sidhu HK, Letty A. A study of eccentric jack-up penetration into infilled footprint craters. Proc 8th Int Conf on the Jack-up Platf: Design, Construction and Operation; 2001 Sep 18-19; City University London, UK. 2001 .

[15] Jardine RJ, Kovacevic N, Hoyle MJR, Sidhu HK, Letty A. Assessing the effects on jackup structures of eccentric installation over infilled craters. Proc Offshore Site Invest and Geotech Conf, Diversity and Sustainability; 2002 Nov 26-28; London, UK. 2002. p. 307-24.

[16] Hartono. Centrifuge model study on spudcan-footprint remediation techniques. Ph.D. thesis, National University of Singapore, 2014.

[17] Hartono, Leung DF, Tho KK, Chow YK. Reaming as mitigation measure for jack-up reinstallation close to existing footprint. Proc 14th Int Conf on the Jack-up Platf: Design, Construction and Operation; 2013 Sep 17-18; City University London, UK. 2013.

[18] Hartono, Tho KK, Leung DF, Chow YK. Centrifuge and numerical modelling of reaming as mitigation measure for spudcan-footprint interaction. Offshore Technol Conf (OTC) Asia; 2014 Mar 25-28; Kuala Lumpur, Malaysia. 2014. OTC 024835MS.

[19] Brennan R, Diana H, Stonor RWP, Hoyle MJR, Cheng C-P, Martin D, et al. Installing jackups in punch-through-sensitive clays. Proc Offshore Technol Conf (OTC); 2006 May 1-4; Houston, USA. 2006. OTC 18268. 
[20] Erbrich CT, Amodio A, Krisdani H, Lam SY, Xu X, Tho KK. Re-visiting Yolla- new insight on spudcan penetration. Proc 15th Int Conf on the Jack-up Platf: Design, Construction and Operation; 2015 Sep15-16; City University London, UK. 2015.

[21] Handidjaja P, Gan CT, Leung CF, Chow YK. Jack-up foundation performance over spudcan footprints analysis of a case history. Proc 12th Int Conf on the Jack-up Platf: Design, Construction and Operation; 2009 Sep 15-16; City University London, UK. 2009.

[22] Grammatikopoulou A, Jardine RJ, Kovacevic N, Potts DM, Hoyle MJR, Hampson KM. Potential solutions to the problem of the eccentric installation of jack-up structures into old footprint craters. Proc Offshore Site Invest and Geotech Conf, Confronting New Challenges and Sharing Knowledge; 2007 Sep 11-13; London, UK. 2007. p. 293300.

[23] Jun MJ, Kim YH, Hossain MS, Cassidy MJ, Hu Y, Sim JU. Numerical investigation of novel spudcan shapes for easing spudcan-footprint interactions. J Geotech Geoenviron Eng (ASCE) 2018;144(9):04018055.

[24] Jun MJ, Kim YH, Hossain MS, Cassidy MJ, Hu Y, Park SG. Optimising spudcan shape for mitigating spudcan-footprint interaction. Appl Ocean Res 2018;79:62-73.

[25] Amodio A, Erbrich C, Murugavel V. Re-visiting Yolla - managing jack-up storm stability; geotechnical assessment. Proc 15th Int Conf on the Jack-up Platf: Design, Construction and Operation; 2015 Sep15-16; City University London, UK. 2015.

[26] Dassault Systemes. ABAQUS , Version 6.11 EF Documentation. Rhode Island: Hibbitt, Karlsson and Sorensen, Inc.; 2012.

[27] Qiu G, Henke S, Grabe J. Application of a coupled Eulerian-Lagrangian approach on geomechanical problems involving large deformations. Computer Geotech 2011;38:30-9.

[28] Chen Z, Tho KK, Leung CF, Chow YK. Influence of overburden pressure and soil rigidity on uplift behavior of square plate anchor in uniform clay. Computer Geotech 2013;52:71-81. 
[29] Tho KK, Chan N, Zhou Y, Liu J, Zhou S. Case study of spudcan re-penetration analysis using large deformation finite element approach. Proc 15th Int Conf on the Jack-up Platf: Design, Construction and Operation; 2015 Sep15-16; City University London, UK. 2015.

[30] Hu P, Wang D, Cassidy MJ, Stanier SA. Predicting the resistance profile of a spudcan penetrating sand overlying clay. Canadian Geotech J 2014;51(10):1151-64.

[31] Hamann T, Qiu G, Grabe J. Application of a Coupled Eulerian-Lagrangian approach on pile installation problems under partially drained conditions. Computer Geotech 2015;63:279-90.

[32] Kim YH, Hossain MS. Dynamic installation of OMNI-Max anchors in clay: Numerical Analysis. Géotechnique 2015;65(12):1029-37.

[33] Kim YH, Hossain MS. Numerical study on pull-out capacity of torpedo anchors in clay. Géotechnique Letters 2016;6(4):275-82.

[34] Kim YH, Hossain MS. Dynamic installation, keying and diving of OMNI-Max anchors in clay. Géotechnique 2017;67(1):78-85.

[35] Zheng J, Hossain MS, Wang D. New design approach for spudcan penetration in nonuniform clay with an interbedded stiff layer. J Geotech Geoenviron Eng (ASCE) 2015;141(4):04015003.

[36] Hu P, Wang D, Stanier SA, Cassidy MJ. Assessing the punch-through hazard of a spudcan on sand overlying clay. Géotechnique 2015;65(11):883-96.

[37] Z.Chen, K.K. Tho, C.F. Leung, Y.K. Chow, Influence of overburden pressure and soil rigidity on uplift behavior of square plate anchor in uniform clay, Computers and Geotechnics 2013, 52:71-81.

[38] K.K. Tho, Z.Chen, C.F. Leung, Y.K. Chow, Pullout behaviour of plate anchor in clay with linearly increasing strength, Canadian Geotechnical Journal 2014, 51(1):92-102.

[39] Menzies D, Roper R. Comparison of jackup rig spudcan penetration methods in clay. roc Offshore Technol Conf (OTC); 2008 May 5-8; Houston, USA. 2008. OTC 19545.

[40] Wang D, Bienen B, Nazem M, Tian Y, Zheng J, Pucker T, et al. Large deformation finite element analyses in geotechnical engineering. Computer Geotech 2015;65:104-14. 
[41] Einav I, Randolph MF. Combining upper bound and strain path methods for evaluating penetration resistance. Int J Numerical Methods Eng 2005;63(14):1991-2016.

[42] Hossain MS, Randolph MF. Effect of strain rate and strain softening on the penetration resistance of spudcan foundations on clay. Int J Geomech (ASCE) 2009;9(3):122-32.

[43] Zhang W. Investigation of spudcan-footprint interaction in clay with a novel implementation of a three-dimensional large deformation finite element method. Ph.D. thesis, The University of Western Australia, 2018.

[44] Zhou H, Randolph MF. Computational techniques and shear band development for cylindrical and spherical penetrometers in strain-softening clay. Int J Geomechanics 2007;7(4):287-295.

[45] Kim YH, Hossain MS, Wang D. Effect of strain rate and strain softening on embedment depth of a torpedo anchor in clay, Ocean Eng 2015;108:704-715.

[46] Needleman A. Material rate dependence and mesh sensitivity in localization problems. Comput Methods Appl Mech Eng 1988;67(1):69-85.

[47] Sluys LJ, De Borst R. Wave propagation and localization in a rate-dependent cracked medium-model formulation and onedimensional examples. Int $\mathbf{J}$ Solids Struct 1992;29(23):2945-2958.

[48] Oka F. Computational modeling of large deformations and the failure of geomaterials. Proc., 16th Int. Conf. on Soil Mechanics and Foundation Engineering; 2005 Sept1215; Osaka, Japan. 2005;1:47-94.

[49] Society of Naval Architects and Marine Engineers (SNAME), Site specific assessment of mobile jack-up units. SNAME Technical and Research Bulletin 5-5A. 1st ed. 3rd revision; 2008.

[50] InSafeJIP. Improved guidelines for the prediction of geotechnical performance of spudcan foundations during installation and removal of jack-up units. Joint Industry Funded Project; 2011.

[51] International Organization for Standardization (ISO). Petroleum natural gas industries Site specific assessment of mobile offshore units - Part 1: Jack-ups; 2012. ISO 199051 
684 [52] Ibsen LB, Roesen HR, Wolf TK, Hansen M, Rasmussen KL. Assessment of p-y curves

685 from numerical methods for a non-slender monopile in cohesionless soil. Proc $23^{\text {rd }} \mathrm{Int}$ Offshore and Polar Eng (ISOPE); 2013 Jun 30- Jul 4; Alaska, USA. 2013. 2:436-43.

[53] Østergaard MU, Knudsen BS, Ibsen LB. P-y curves for bucket foundations in sand using finite element modelling. Proc $3^{\text {rd }}$ Int Symp on Frontiers in Offshore Geotech (ISFOG); 2015 Jun 10-12; Oslo, Norway. 2015. 1:343-8.

[54] Gan CT. Centrifuge model study on spudcan-footprint interaction [dissertation]. Singapore: National University of Singapore; 2009.

[55] Hossain MS, Dong D, Gaudin C, Kong VW. Skirted spudcans and perforation drilling for installation of spudcans close to existing footprints. Proc Offshore Site Invest and Geotech Conf, Integrated Geotechnologies- Present and Future; 2012 Sep 12-14; London, UK. 2012. p. 597-605.

[56] Hossain MS, Dong X. Extraction of spudcan foundations in single and multilayer soils. J Geotech Geoenviron Eng (ASCE) 2014;140(1):70-184.

[57] Erbrich CT. Australian frontiers - spudcans on the edge. Proc $1^{\text {st }}$ Int Symp on Frontiers in Offshore Geotech (ISFOG); 2005 Sep 19-21; Perth, Australia. 2005. p. 49-75. 
Nomenclature

\begin{tabular}{|c|c|}
\hline$A_{\text {hull }}$ & cross-sectional area of equivalent hull beam model \\
\hline A $_{\text {hull bottom }}$ & bottom area of jack-up rig hull \\
\hline$A_{\text {leg }}$ & cross-sectional area of equivalent leg beam model \\
\hline$A_{\text {net }}$ & net area of spudcan at largest section \\
\hline$A_{r \& c}$ & cross-sectional area of rack and chord \\
\hline $\mathrm{D}$ & spudcan diameter at largest section \\
\hline $\mathrm{D}_{\text {brace }}$ & brace diameter \\
\hline $\mathrm{D}_{\text {chord }}$ & chord diameter \\
\hline $\mathrm{D}_{\mathrm{F}}$ & footprint diameter \\
\hline $\mathrm{d}$ & penetration depth of spudcan base \\
\hline $\mathrm{d} / \mathrm{D}_{\text {critical }}$ & normalised critical penetration depth \\
\hline $\mathrm{d}_{\mathrm{h}}$ & hole diameter \\
\hline $\mathrm{E}_{\text {steel }}$ & Young's modulus of steel \\
\hline $\mathrm{e}_{\text {leg }}$ & eccentricity of leg \\
\hline $\mathrm{G}$ & shear modulus of foundation soil \\
\hline $\mathrm{g}$ & acceleration of gravity \\
\hline $\mathrm{H}$ & horizontal force at spudcan base level \\
\hline $\mathrm{H}_{\max }$ & maximum horizontal force at spudcan base level \\
\hline $\mathrm{I}_{\text {hull }}$ & moment of inertia of equivalent hull beam model \\
\hline$I_{\text {leg }}$ & moment of inertia of equivalent leg beam model \\
\hline $\mathrm{I}_{\mathrm{r} \& \mathrm{c}}$ & moment of inertia of rack and chord \\
\hline $\mathrm{K}$ & column effective length factor \\
\hline $\mathrm{K}_{\text {buoy }}$ & spring stiffness of buoyancy \\
\hline $\mathrm{K}_{\mathrm{dV}}, \mathrm{K}_{\mathrm{dH}}$ and $\mathrm{K}_{\mathrm{dM}}$ & $\begin{array}{l}\text { vertical, horizontal and moment foundation stiffness depth } \\
\text { factors }\end{array}$ \\
\hline $\mathrm{K}_{\mathrm{ISO}}$ & foundation stiffness calculated by ISO guidance (2012) \\
\hline $\mathrm{K}_{\mathrm{V}, \mathrm{ISO}}, \mathrm{K}_{\mathrm{H}, \text { ISO }}$ and $\mathrm{K}_{\mathrm{M}, \mathrm{ISO}}$ & $\begin{array}{l}\text { vertical, horizontal and moment foundation stiffness calculated } \\
\text { by ISO guidance (2012) }\end{array}$ \\
\hline $\mathrm{K}_{\mathrm{LDFE}}$ & foundation stiffness calculated by LDFE analysis \\
\hline $\mathrm{K}_{\mathrm{V}, \text { LDFE}}, \mathrm{K}_{\mathrm{H}, \mathrm{LDFE}}$ and $\mathrm{K}$ & vertical, horizontal and moment foundation stiffness calculated \\
\hline M, LDFE & by LDFE analysis \\
\hline $\mathrm{L}_{\text {bay }}$ & bay length \\
\hline
\end{tabular}




\begin{tabular}{|c|c|}
\hline $\mathrm{L}_{\text {leg }}$ & length of leg \\
\hline $\mathrm{L}_{\text {rack }}$ & length of rack \\
\hline M & moment at spudcan base level \\
\hline $\mathbf{M}_{\max }$ & maximum moment at spudcan base level \\
\hline $\mathrm{M}_{\mathrm{t}}$ & moment at leg top \\
\hline $\mathrm{RP}$ & reference point that is the intersection point of the centre line \\
\hline & and largest cross section of the spudcan (see Fig. 3) \\
\hline $\mathrm{R}_{\mathrm{x}}, \mathrm{R}_{\mathrm{y}} \& \mathrm{R}_{\mathrm{z}}$ & rotational displacement \\
\hline$r_{r \& c}$ & radius of gyration of rack and chord \\
\hline $\mathrm{S}_{\mathrm{t}}$ & soil sensitivity \\
\hline $\mathrm{s}_{\mathrm{u}}$ & undrained shear strength \\
\hline $\mathrm{S}_{\mathrm{u}, \mathrm{ref}}$ & reference undrained shear strength \\
\hline$t_{\text {brace }}$ & brace thickness \\
\hline$t_{\text {chord }}$ & chord thickness \\
\hline $\mathrm{t}_{\text {rack }}$ & rack thickness \\
\hline $\mathrm{U}_{\mathrm{x}}, \mathrm{U}_{\mathrm{y}} \& \mathrm{U}_{\mathrm{z}}$ & directional displacement \\
\hline $\mathrm{V}$ & vertical force \\
\hline $\mathrm{v}$ & spudcan penetration velocity \\
\hline $\mathrm{z}$ & penetration depth below soil surface \\
\hline $\mathrm{Z}_{\mathrm{F}}$ & footprint depth \\
\hline$\alpha_{b}$ & spudcan base angle \\
\hline$\beta$ & distance between the footprint centre and spudcan centre \\
\hline$\Delta \mathrm{F}_{\text {buoy. }}$ & $\begin{array}{l}\text { change in static buoyancy force on the hull bottom (or the } \\
\text { required force for } \Delta s \text { ) }\end{array}$ \\
\hline$\Delta \mathrm{s}$ & change in hull vertical displacement \\
\hline$\Delta \delta_{\mathrm{a}}, \Delta \delta_{\mathrm{b}}, \Delta \delta_{\mathrm{c}}, \Delta \delta_{\mathrm{d}}$ & relative deflection at four different locations (see Fig. 9) \\
\hline$\Delta \theta_{\mathrm{a}}, \Delta \theta_{\mathrm{b}}, \Delta \theta_{\mathrm{c}}, \Delta \theta_{\mathrm{d}}$ & relative rotation at four different locations (see Fig. 9) \\
\hline$\delta$ & spudcan lateral displacement at RP \\
\hline$\delta_{\max }$ & maximum spudcan lateral displacement \\
\hline$\delta_{\text {rem }}$ & remoulded strength ratio \\
\hline$\dot{\gamma}$ & shear strain rate \\
\hline$\dot{\gamma}_{\text {ref }}$ & reference shear strain rate \\
\hline
\end{tabular}


$\lambda$

$\mu$

$\theta$

$\theta_{\max }$

$\rho_{\text {sea }}$

$\sigma_{\text {axial }}$

$\sigma_{\text {beam }}$

$\sigma_{\text {beam,max }}$

$\sigma_{\text {bending }}$

$\sigma_{\mathrm{E}}$

$\sigma_{\text {criteria }}$

$\sigma_{\text {yield }}$

v

$\omega$

$\xi$

$\xi_{95}$ the ratio of the distance between the footprint centre and spudcan centre, $\beta$, and the spudcan diameter

rate parameter for logarithmic expression

spudcan rotation at $\mathrm{RP}$

maximum rotation at $\mathrm{RP}$

density of sea water

structural axial stress

structural beam stress

maximum structural beam stress

structural bending stress

Euler's buckling strength

design criteria (ISO, 2012)

yield stress of steel

Poisson's ratio of foundation soil

reduction factor of foundation stiffness

cumulative plastic shear strain

cumulative plastic shear strain required for $95 \%$ remoulding 
Table 1. Main dimensions and properties of a simplified jack-up rig model

\begin{tabular}{|c|c|}
\hline Main dimensions and properties & Value \\
\hline Total leg length & $180(\mathrm{~m})$ \\
\hline Leg length between hull and seabed & $150(\mathrm{~m})$ \\
\hline Each side length of hull (hull shape: equilateral triangle) & $80(\mathrm{~m})$ \\
\hline \multirow{2}{*}{ Cross-sectional area of equivalent leg beam model, $\mathrm{A}_{\text {leg }}$} & $0.71\left(\mathrm{~m}^{2}\right)$ \\
\hline & $\begin{array}{c}0.35\left(\mathrm{~m}^{2}\right) \text { for a symmetric } \\
\text { condition }\end{array}$ \\
\hline \multirow{2}{*}{ Cross-sectional area of equivalent hull beam model, $\mathrm{A}_{\text {hull }}$} & $2.79\left(\mathrm{~m}^{2}\right)$ \\
\hline & $\begin{array}{c}1.40\left(\mathrm{~m}^{2}\right) \text { for a symmetric } \\
\text { condition }\end{array}$ \\
\hline \multirow{2}{*}{ Moment of inertia of equivalent leg beam model, $\mathrm{I}_{\mathrm{leg}}$} & $21.26\left(\mathrm{~m}^{4}\right)$ \\
\hline & $\begin{array}{c}10.63\left(\mathrm{~m}^{4}\right) \text { for a symmetric } \\
\text { condition }\end{array}$ \\
\hline \multirow{2}{*}{ Moment of inertia of equivalent hull beam model, $\mathrm{I}_{\text {hull }}$} & $55.51\left(\mathrm{~m}^{4}\right)$ \\
\hline & $\begin{array}{c}27.76\left(\mathrm{~m}^{4}\right) \text { for a symmetric } \\
\text { condition }\end{array}$ \\
\hline
\end{tabular}

704 
Table 2. Summary of 3D LDFE analyses performed

\begin{tabular}{|c|c|c|c|c|c|c|c|c|c|c|c|c|}
\hline \multirow[b]{2}{*}{ Group } & \multirow{2}{*}{$\begin{array}{l}\text { Spudcan } \\
\text { shape }\end{array}$} & \multirow[b]{2}{*}{$\begin{array}{l}\mathrm{s}_{\mathrm{u}, \mathrm{ref}} \\
(\mathrm{kPa})\end{array}$} & \multirow{2}{*}{$\begin{array}{l}\text { Footprint } \\
\text { depth, } \mathrm{Z}_{\mathrm{F}} \\
(\mathrm{m})\end{array}$} & \multirow{2}{*}{$\begin{array}{l}\text { Footprint } \\
\text { diameter, } \\
\mathrm{D}_{\mathrm{F}}(\mathrm{m})\end{array}$} & \multirow{2}{*}{$\begin{array}{l}\text { Offset } \\
\text { distance } \\
, \beta(\mathrm{m})\end{array}$} & \multirow{2}{*}{\multicolumn{2}{|c|}{ Penetration scenario }} & \multicolumn{4}{|c|}{ Spudcan response } & \multirow[b]{2}{*}{ Note } \\
\hline & & & & & & & & $\begin{array}{l}\mathrm{H}_{\max } \\
(\mathrm{MN})\end{array}$ & $\begin{array}{l}\mathrm{M}_{\max } \\
(\mathrm{MN}-\mathrm{m})\end{array}$ & $\begin{array}{l}\delta_{\max } \\
(\mathrm{m})\end{array}$ & $\begin{array}{l}\theta_{\max } \\
\left(^{\circ}\right)\end{array}$ & \\
\hline \multirow{6}{*}{ I } & \multirow{6}{*}{$\begin{array}{l}\text { Generic } \\
\text { spudcan }\end{array}$} & \multirow{6}{*}{$\begin{array}{l}{ }^{*} \text { Soft } \\
\text { clay }\end{array}$} & \multirow{6}{*}{$0.33 \mathrm{D}$} & \multirow{6}{*}{$2.0 \mathrm{D}$} & \multirow{6}{*}{$0.55 \mathrm{D}$} & \multirow{2}{*}{\multicolumn{2}{|c|}{$\begin{array}{l}\text { Fixed head condition } \\
\text { Preloading A }\left(\mathrm{K}_{\mathrm{ISO}}\right)\end{array}$}} & 1.02 & 13.1 & - & - & \multirow{6}{*}{$\begin{array}{l}\text { Effect of } \\
\text { global } \\
\text { response } \\
\text { and large } \\
\text { sliding }\end{array}$} \\
\hline & & & & & & & & 0.94 & 13.8 & 0.49 & -0.23 & \\
\hline & & & & & & \multirow{4}{*}{$\begin{array}{l}\text { Preloading B } \\
\left(\mathrm{K}_{\mathrm{LDFE}}\right)\end{array}$} & $\omega=1.0$ & 0.93 & 13.6 & 0.55 & -0.13 & \\
\hline & & & & & & & $\omega=0.5$ & 0.75 & 13.7 & 2.67 & -0.11 & \\
\hline & & & & & & & $\omega=0.3$ & 0.56 & 13.4 & 3.98 & -0.08 & \\
\hline & & & & & & & $\omega=1.0$ & 0.25 & 12.5 & 6.23 & -0.04 & \\
\hline \multirow{2}{*}{ II } & \multirow{2}{*}{$\begin{array}{l}\text { Generic } \\
\text { spudcan }\end{array}$} & \multirow{2}{*}{$\begin{array}{l}{ }^{\#} \text { Very } \\
\text { Stiff } \\
\text { clay } \\
\end{array}$} & \multirow{2}{*}{$0.66 \mathrm{D}$} & \multirow{2}{*}{$1.0 \mathrm{D}$} & \multirow{2}{*}{$0.50 \mathrm{D}$} & \multicolumn{2}{|c|}{ Fixed head condition } & 7.55 & 73.0 & - & - & \multirow{2}{*}{$\begin{array}{l}\text { Leg } \\
\text { damage }\end{array}$} \\
\hline & & & & & & \multicolumn{2}{|c|}{ Preloading A ( $\left.\mathrm{K}_{\mathrm{ISO}}\right)$} & 6.35 & 72.0 & 3.43 & -1.37 & \\
\hline \multirow[b]{3}{*}{ III } & \multirow{3}{*}{$\begin{array}{l}\text { Novel } \\
\text { spudcan }\end{array}$} & \multirow{2}{*}{$\begin{array}{l}\text { * Soft } \\
\text { clay }\end{array}$} & \multirow{2}{*}{$0.33 \mathrm{D}$} & \multirow{2}{*}{$2.0 \mathrm{D}$} & \multirow{2}{*}{$0.55 \mathrm{D}$} & \multirow{2}{*}{$\begin{array}{l}\text { Preloading B } \\
\left(\mathrm{K}_{\mathrm{LDFE}}\right)\end{array}$} & $\omega=1.0$ & 0.64 & 13.8 & 0.40 & -0.10 & \multirow{3}{*}{$\begin{array}{l}\text { Effect of } \\
\text { novel } \\
\text { spudcan }\end{array}$} \\
\hline & & & & & & & $\omega=0.1$ & 0.27 & 12.2 & 3.72 & -0.05 & \\
\hline & & $\begin{array}{l}{ }^{\#} \text { Very } \\
\text { Stiff } \\
\text { clay }\end{array}$ & $0.66 \mathrm{D}$ & $1.0 \mathrm{D}$ & $0.50 \mathrm{D}$ & \multicolumn{2}{|c|}{ Preloading A $\left(\mathrm{K}_{\mathrm{ISO}}\right)$} & 4.18 & 58.2 & 2.35 & 1.06 & \\
\hline
\end{tabular}

\#Very stiff clay: $\mathrm{s}_{\mathrm{u}, \mathrm{ref}}=50.0(\mathrm{kPa})$ 
710 Table 3. Displacement and rotation at each location (locations a, b, c and d) at the penetration depth with $\mathrm{H}_{\max }$ and $\theta_{\max }$

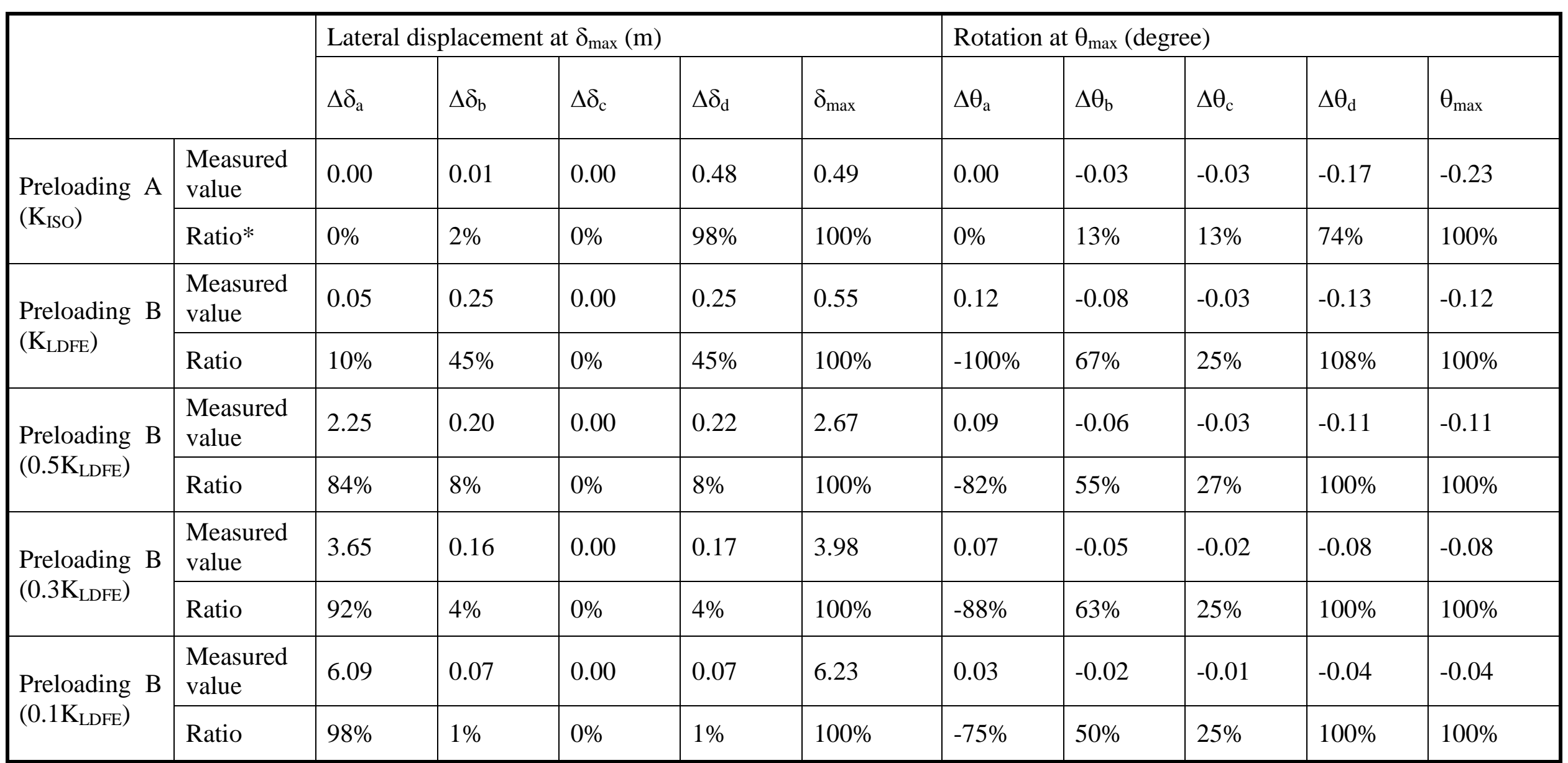

711 Note: $*$ Ratio: $\Delta \delta_{\text {Location }} / \delta_{\max } \& \Delta \theta_{\text {Location }} / \theta_{\max }$ 
713 Table 4. Dimensions and properties for chord and bracing

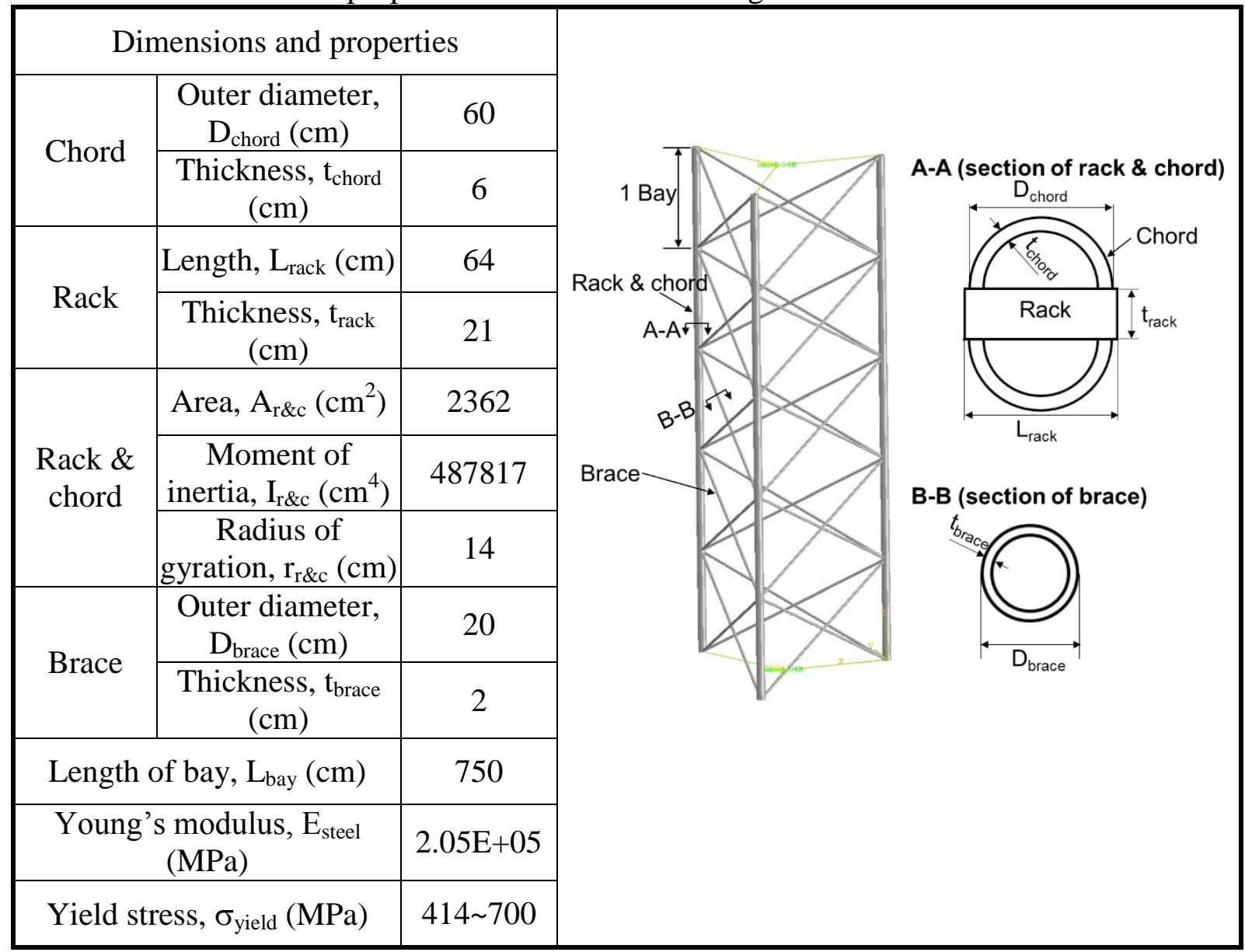

714

715

716 


\section{List of Figures}

Fig. 1. Jack-up reinstallation on a footprint

Fig. 2. Global jack-up rig model and footprint shape: (a) Simplified jack-up rig model; (b) Conical shallow footprint; (c) Cylindrical deep footprint

Fig. 3. Spudcan shape: (a) Generic spudcan; (b) Novel spudcan

Fig. 4. Preloading A, leg-by-leg preloading: pre-embedment of two spudcans into the flat seabed and later penetration of a spudcan near a footprint

Fig. 5. Preloading B, simultaneous preloading: simultaneous installation of three legs

Fig. 6. Foundation stiffness for the generic spudcan in soft clay: (a) Vertical stiffness; (b) Horizontal stiffness; (c) Rotational stiffness

Fig. 7. Resistance forces and deflections at RP induced by spudcan-footprint interaction with a fixed head condition, preloading $\mathrm{A}\left(\mathrm{K}_{\mathrm{ISO}}\right)$ and preloading $\mathrm{B}\left(\omega \mathrm{K}_{\mathrm{LDFE}} ; \omega=0.1,0.3\right.$, 0.5 and 1.0) in soft clay and a shallow conical footprint: (a) Horizontal resistance force; (b) Vertical resistance force; (c) Moment resistance; (d) Lateral displacement; (e) Rotation

Fig. 8. Failure mechanism in soft clay: (a) $d / D=0.1$; (b) $d / D=0.2$; (c) $d / D=0.3$; (d) $d / D=$ 0.38

Fig. 9. Schematic diagram for hull deflection and rotation induced by footprint-spudcan interaction

Fig. 10. Measured horizontal resistance force and lateral displacement at foundation spring

Fig. 11. Resistance forces and spudcan deflections induced by spudcan-footprint interaction with a fixed head condition and preloading $\mathrm{A}\left(\mathrm{K}_{\mathrm{ISO}}\right)$ in very stiff clay and a deep cylindrical footprint: (a) Horizontal resistance force; (b) Vertical resistance force; (c) Moment resistance; (d) Lateral displacement; (e) Rotation

Fig. 12. Failure mechanism of a generic spudcan with a fixed head condition and preloading A ( $\left.\mathrm{K}_{\mathrm{ISO}}\right)$ in very stiff clay and a deep cylindrical footprint: (a) d/D $=0.2 ;$ (b) d/D $=$ $0.4 ;(c) d / D=0.6 ;(d) d / D=0.7$

Fig. 13. Beam stress on a leg just below hull in very stiff clay and a deep cylindrical footprint (unit: MPa): (a) Moment at RP and leg top; (b) Structural beam stress components (beam, axial and bending stress); (c) Structural beam stress of a leg just below the jack-up rig hull with the normalised penetration depth

Fig. 14. Leg structural model and boundary conditions for the detailed leg structural analysis 
Fig. 15. Detailed structural analysis results on leg just below hull (generic spudcan) in very stiff clay and a deep cylindrical footprint (unit: $\mathrm{MPa}$ )

Fig. 16. Resistance forces and spudcan deflections induced by spudcan-footprint interaction (generic, novel and large novel spudcan) in soft clay and a shallow conical footprint for the large deflection case of preloading $\mathrm{B}$ ( $\left.\mathrm{K}_{\mathrm{LDFE}} \mathrm{vs} 0.1 \mathrm{~K}_{\mathrm{LDFE}}\right)$ : a) Horizontal resistance force; (b) Vertical resistance force; (c) Moment resistance; (d) Lateral displacement; (e) Rotation

Fig. 17. Failure mechanism of the novel spudcan for the large deflection case: (a) $d / D=0.1$; (b) $\mathrm{d} / \mathrm{D}=0.2 ;$ (c) $\mathrm{d} / \mathrm{D}=0.3 ;$ (d) $\mathrm{d} / \mathrm{D}=0.38$

Fig. 18. Resistance forces and spudcan deflections induced by spudcan-footprint interaction (generic vs novel spudcan) with a fixed head condition and preloading A ( $\left.\mathrm{K}_{\mathrm{ISO}}\right)$ in very stiff clay and a deep cylindrical footprint: (a) Horizontal resistance force; (b) Vertical resistance force; (c) Moment resistance; (d) Lateral displacement; (e) Rotation

Fig. 19. Failure mechanism of the novel spudcan for the leg failure case of preloading A $\left(K_{I S O}\right):(a) d / D=0.2 ;$ (b) d/D = 0.4; (c) d/D = 0.6; (d) d/D = 0.7

Fig. 20. Beam stress and detailed structural analysis of a leg just below the hull for the leg failure case (novel spudcan) (unit: MPa): (a) Structural beam stress of a leg just below the jack-up rig hull with the normalised penetration depth; (b) Detailed structural analysis results of a leg just below the hull 